\title{
MOLECULAR CHARACTERIZATION OF THE Bacillus thuringiensis (BERLINER) STRAINS 344 AND 1644, EFFICIENT AGAINST FALL ARMYWORM Spodoptera frugiperda (J. E. SMITH)
}

\author{
FERNANDO HERCOS VALICENTE ${ }^{1}$ and UBIRACI GOMES DE PAULA LANA ${ }^{1}$
}

${ }^{1}$ Embrapa Milho e Sorgo, C.P. 151, 35701-970 - Sete Lagoas, MG.

E-mail:valicent@cnpms.embrapa.br

$\overline{\text { Revista Brasileira de Milho e Sorgo, v.7, n.3, p. 195-209, } 2008}$

\begin{abstract}
Bacillus thuringiensis (Berliner) strains 344 and 1644 belonging to the CNPMS/Embrapa (Maize and Sorghum National Research Center) Microorganism Bank, located in Sete Lagoas, MG, showed to be highly efficient in controlling fall armyworm, Spodotpera frugiperda (J.E. Smith). Strains 344 and 1644 were isolated from soil samples originated from Iguassu Falls and Rolândia, respectively, Paraná State, Brazil. While strain 344 harbors crylAb, crylB, crylE and crylFb genes, strain 1644 showed cry1B, cry $1 \mathrm{C}$, and cry $1 \mathrm{D}$ and cry $1 \mathrm{Fb}$ genes. The strain 344 crystal has bipyramidal shape and showed $\mathrm{LC}_{50}$ equal to $8.21 \times 10^{6}$ spores $/ \mathrm{mL}$. Strain 1644 has cuboid crystal and showed $\mathrm{LC}_{50}$ equal to $2.07 \times 10^{6}$ spores $/ \mathrm{mL}$. Comparative analysis of protein profile, plasmid and amplification with primers ERIC allowed the differentiation of the evaluated strains.
\end{abstract}

Key words: insect pathology, Bacillus thuringiensis, cry genes.

\section{CARACTERIZAÇÃO MOLECULAR DAS CEPAS 344 E 1644 DE Bacillus thuringiensis (BERLINER), EFICIENTES NO CONTROLE DA LAGARTA-DO-CARTUCHO, Spodoptera frugiperda (J. E. SMITH)}

RESUMO - As cepas 344 e 1644 de Bacillus thuringiensis (Berliner), do Banco de Microrganismos da Embrapa, situada em Sete Lagoas, MG, mostram-se muito eficientes no controle da lagarta-do-cartucho, Spodoptera frugiperda (J.E. Smith). Essas cepas foram isoladas de amostras de solo das cidades de Foz do Iguaçu e Rolândia, respectivamente, no estado do Paraná, Brasil. Enquanto na cepa 344 estão presentes os genes crylAb, crylB, crylE e crylFb, a cepa 1644 apresentou os genes crylB, crylC, crylD e crylFb. $\mathrm{O}$ cristal da cepa 344 possui formato bipiramidal e apresentou $\mathrm{CL}_{50}$ igual a $8,21 \times 10^{6}$ esporos $/ \mathrm{mL}$. Já a cepa 1644 possui cristal cubóide e $\mathrm{CL}_{50}$ igual a 2,07 x $10^{6}$ esporos $/ \mathrm{mL}$. 
Análises comparativas dos perfis protéico, plasmidial e por amplificação com primers ERIC permitiram a diferenciação das cepas avaliadas.

Palavras-chave: patologia de insetos, Bacillus thuringiensis, genes cry.

Fall armyworm, Spodoptera frugiperda, is considered one of the most important insect pests in maize crop in Brazil and may reduce yield production up to $34 \%$ (Carvalho, 1970). The life cycle of this insect pest is completed within 30 days under laboratory conditions, and the number of eggs may vary from 100 to 200 eggs per clutch/female and a total of 1500 to 2000 eggs/female. Therefore, the potential damage that this insect may cause in the field is high. Chemical control is widely used to control this insect, however efficient Bacillus thuringiensis $(B t)$ strains may become feasible to control $S$. frugiperda in the field.

Bacillus thuringiensis is a Gram-positive bacterium that occurs naturally in soil, water, dead insects and grain dust (Lambert \& Peferoen, 1992). During the stationary and/or sporulation phase, this bacterium produces a sporangium that contains an endospore and one or more crystalline proteinaceous inclusions called $\delta$-endotoxins. These $\delta$-endotoxins are toxic to a great number of insects and turns $B t$ into a valuable tool to be used in the Insect Pest Management (IPM). More than 200 different genes coding for $\delta$-endotoxins were already identified, and the vast majority are active against a few order of insects. The activity of the $\delta$-endotoxins is restricted to the midgut of the insect. When larvae were fed with a great amount of toxin, they suffer paralysis and die (Glare \& O'Callaghan, 2000). The proteins that form these crystals comprises 20 to $30 \%$ of the total protein of the bacteria during the sporulation phase (Boucias \& Pendland, 1998). Molecular weight of these crystals varies depending on the method of the dissolution, and upon solubilization in basic $\mathrm{pH}$, become protoxins that are composed of Cry proteins or insecticidal crystal proteins (ICPs) with molecular masses ranging from 25 to $140 \mathrm{kDa}$ (Céron et al., 1995; Berhnard et al., 1997). Usually, crystals that are generally bipyramidal in shape are active against lepidopterans. Crystal shapes also include triangles, cuboids, ovoid, flat, and amorphous in many subspecies. Kronstad et al. (1983) report that cry genes occur in plasmids and in some subspecies in bacterial chromosomes. Interest in $B t$ plasmids started at the end of the 1970s when a correlation was established between the formation of crystals and the presence of certain plasmids. Later on, attention was focused on the location of cry genes in plasmids and on the transfer of plasmids between different strains of $B t$ (González et 
al., 1982). However, little attention was paid to the importance of plasmid patterns as a tool for strain characterization.

Boucias \& Pendland (1998) estimate $60,000 \mathrm{Bt}$ isolates in collections all over the world. Embrapa Maize and Sorghum Research Center, located in Sete Lagoas, Brazil, has a Bt Bank with more than 4500 isolates originated from soil samples, dead insect and grain dust.

In terms of specificity, $B t$ shows differences in toxicity regarding insect species, but it is not constant within the same order (e.g. Lepidoptera). Dramatic differences in sensitivity were found among species, i.e. Spodoptera spp. are difficult to control with $B t$ based bioinsecticides (strain HD1), however Heliothis virescens and Plutella xylostella are not (Baum et al., 1999). Beegle \& Yamamoto (1992) also confirmed that $B t$ is not much efficient in controlling $S$. frugiperda. Aronson et al. (1991) reported that crystal solubility is the main factor of the $B t$ insecticidal efficiency and suggested that this factor may explain the low susceptibility of $S$. frugiperda to Bt. So far, Bt kurstaki has been the most used strain ever in commercial products, and some of them are the strain HD-1 belonging to the Dulmage collection (Nakamura \& Dulmage, 1988).

Serotyping is the most widely accepted subspecific classification technique for varieties of $B t$, even if strains from the same serovar do not necessarily share the biochemical, genetic, or toxicological attributes. Although serotyping is a reliable and straightforward technique, it is performed only in a few laboratories around the world, in particular the Pasteur Institute in France, where a $B t$ collection is held. Therefore, alternative techniques, especially molecular techniques, are being developed to try to overcome those constrains (Phucharoen et al., 1999).

The enterobacterial repetitive intergenic consensus (ERIC) sequences, also known as intergenic repeat units (IRUs) are present in many copies in the genomes of Escherichia coli, Salmonella typhimurium, and other enterobacteria (Hulton et al., 1991). In ERICPCR a band pattern is obtained by amplification of genomic DNA located between ERIC elements or between ERIC elements and other repetitive DNA sequences and generate distinctive electrophoretic patterns among different strains. ERIC-PCR involves the use of primers of 22 nucleotides with high homology to repetitive intergenic sequences that are dispersed throughout the procaryotic kingdom (Versalovic et al., 1991).

Two Bt strains isolated in Paraná State, Brazil, showed to be very efficient in controlling fall armyworm in laboratory bioassays. The objectives of this work were to characterize these strains using different molecular techniques as a valuable routine characterization and check their potential to be used against fall armyworm in the field. 


\section{Material and Methods}

B. thuringiensis strains: Strains were isolated, used and kindly provided by Valicente \& Barreto (2003). These authors showed that strains 344 and 1644 were the most promising in preliminary tests against fall armyworm larvae.

Bioassay with $B$. thuringiensis and $\mathrm{LC}_{50}$ : Two-day old healthy $S$. frugiperda larvae were used to determine the efficiency of each strain and the laboratory conditions were $25^{\circ} \mathrm{C}, 70 \%$ humidity and $14 \mathrm{~h}$ photophase. The insects were reared in artificial diet and transferred and maintained individually in $50 \mathrm{~mL}$ disposable plastic cups, each one containing $5.0 \mathrm{~g}$ of artificial diet previously immersed in $B t$ suspension containing spores and crystals. This suspension was obtained by scrapping $B t$ colonies from the plates and the concentration varied from $10^{3}$ to $10^{8}$ spores $/ \mathrm{mL}$. Mortality was daily evaluated. Four replicates with twenty-five larvae per bioassay were used. $\mathrm{LC}_{50}$ was obtained using two-day old larvae. MSTAT software was used to calculate the $\mathrm{LC}_{50}$.

PCR - cry1 genes: PCR was performed using fresh DNA that was isolated using $B t$ colony grown overnight in solid medium. For DNA isolation a loopful of strains 344 and 1644, were mixed with $100 \mu \mathrm{L}$ distilled autoclaved water, frozen at $-80^{\circ} \mathrm{C}$ for 15 minutes and immediately after immersed into boiling water for five minutes. Primers were selected from the highly conserved regions of the cryl genes. Also, it was used cryl gene primers designed by Cerón et al. (1994) and Cerón et al. (1995). Table 1 shows the sequence of each primer, the cryl gene subgroup identified and the predicted size of the PCR product. Identification of known cryI genes was done using $5 \mu \mathrm{L}$ of DNA sample with $1.5 \mathrm{U} \mathrm{Taq}$ DNA polymerase (Invitrogen), $250 \mathrm{nM}$ each deoxynucleoside triphosphate, $50 \mathrm{mM} \mathrm{KCl}$, $20 \mathrm{mM}$ Tris- $\mathrm{HCl}$ ( $\mathrm{pH}$ 8.4), $400 \mathrm{nM}$ each primer and $3 \mathrm{mM} \mathrm{MgCl}_{2}$, in a final volume of $25 \mu \mathrm{L}$. PCR cycles were as follows: a single denaturation step for $3 \mathrm{~min}$ at $95^{\circ} \mathrm{C}$, followed by 29 cycles, each consisting of a denaturation step at $95^{\circ} \mathrm{C}$ for $1 \mathrm{~min}$, annealing temperature depending on the primer set used (usually between 50 and $57^{\circ} \mathrm{C}$ ) for $1 \mathrm{~min}$, and extension for $1 \mathrm{~min}$ at $72^{\circ} \mathrm{C}$ and a final extension step at $72^{\circ} \mathrm{C}$ for 5 minutes. To avoid false negatives, each PCR reaction was performed at least three times. PCR products were analyzed using a $3 \%$ agarose gel electrophoresis in TAE buffer 1X (40 mM Tris-acetate, $1 \mathrm{mM}$ EDTA $\mathrm{pH}$ $8.0)$ at $110 \mathrm{~V}$ for $1 \mathrm{~h}$ and stained with ethidium bromide solution $(1 \mu \mathrm{g} / \mathrm{mL})$ for $30 \mathrm{~min}$. The results were visualized under a UV light using Gel Logic 200 (Kodak, Rochester, USA).

Genomic DNA Extraction: Fresh $30 \mathrm{~mL}$ LB broth cultures of strains 344 and 1644 were centrifuged at $3000 \times \mathrm{g}$ for $5 \mathrm{~min}$ at $4^{\circ} \mathrm{C}$, and the pellets were washed in $10 \mathrm{~mL}$ of $\mathrm{J}$ buffer (1 M Tris-HCl, 0.1 M EDTA, 0.15 M 
TABLE 1. Primers used for cryl genes characterization of Bacillus thuringiensis.

\begin{tabular}{|c|c|c|c|c|}
\hline Name & Sequence $\left(5^{\prime}-3^{\prime}\right)$ & Gene & $\begin{array}{c}\text { Fragment } \\
\text { (bp) }\end{array}$ & Reference \\
\hline CJ01 & TTATACTTGGTTCAGGCCC & $\operatorname{cryIA}(a)$ & \multirow[t]{2}{*}{246} & \multirow[t]{2}{*}{ Céron et al., 1994} \\
\hline CJ02 & TTGGAGCTCTCAAGGTGTAA & $\operatorname{cryI} A(d)$ & & \\
\hline CJ03 & CAGCCGATTTACCTTCTA & $\operatorname{cry} I A(d)$ & \multirow[t]{2}{*}{171} & \multirow[t]{2}{*}{ Céron et al., 1994} \\
\hline CJ02 & TTGGAGCTCTCAAGGTGTAA & $\operatorname{cryIA}(d)$ & & \\
\hline CJ04 & AACAACTATCTGTTCTTGAC & $\operatorname{cryI} A(b)$ & \multirow{2}{*}{216} & \multirow{2}{*}{ Céron et al., 1994} \\
\hline CJ05 & СТСТТАТТАТАСТТАСАСТАС & $\operatorname{cryI} A(c)$ & & \\
\hline CJ06 & GTTAGATTAAATAGTAGTGG & $\operatorname{cryI} A(c)$ & \multirow[t]{2}{*}{180} & \multirow[t]{2}{*}{ Céron et al., 1994} \\
\hline CJ07 & TGTAGCTGGTACTGTATTG & $\operatorname{cryI} I(c)$ & & \\
\hline CJ08 & CTTCATCACGATGGAGTAA & $\operatorname{cryIB}$ & \multirow[t]{2}{*}{367} & \multirow[t]{2}{*}{ Céron et al., 1994} \\
\hline CJ09 & CATAATTTGGTCGTTCTGTT & cryIB & & \\
\hline CJ10 & AAAGATCTGGAACACCTTT & cryIC & \multirow[t]{2}{*}{130} & \multirow[t]{2}{*}{ Céron et al., 1994} \\
\hline CJ11 & САААСТСТАААТССТТТСАС & cryIC & & \\
\hline CJ12 & CTGCAGCAAGCTATCCAA & cryID & \multirow[t]{2}{*}{290} & \multirow[t]{2}{*}{ Céron et al., 1994} \\
\hline CJ13 & ATTTGAATTGTCAAGGCCTG & cryID & & \\
\hline CJ14 & GGAACCAAGACGAACTATTGC & cryIEa & 147 & \multirow[t]{2}{*}{ Céron et al.,1995 } \\
\hline CJ15 & GGTTGAATGAACCCTACTCCC & cryIEb & 147 & \\
\hline CJ16 & TGAGGATTCTCCAGTTTCTGC & cryIFa & 177 & \multirow[t]{2}{*}{ Céron et al.,1995 } \\
\hline CJ17 & CGGTTACCAGCCGTATTTCG & cryIFb & 177 & \\
\hline Cry1Ab51320F & AATTTGCCATCCGCTGTA & $\operatorname{cryl} A b$ & 418 & \multirow{2}{*}{$\begin{array}{l}\text { Valicente (data } \\
\text { not published) }\end{array}$} \\
\hline Cry1Ab51740R & TTGTGGTAGAAGCGTAGCGA & crylAb & 418 & \\
\hline
\end{tabular}

$\mathrm{NaCl}[\mathrm{pH}$ 8.0]). Pellets were resuspended in $4 \mathrm{~mL}$ of $\mathrm{J}$ buffer, and lysozyme was added to a final concentration of $4 \mathrm{mg} / \mathrm{mL}$, followed by incubation at $37^{\circ} \mathrm{C}$ for $30 \mathrm{~min}$. Then, 10 $\mu \mathrm{L}$ of RNase $(10 \mathrm{mg} / \mathrm{mL})$ were added, and suspensions were incubated for $15 \mathrm{~min}$ at $37^{\circ} \mathrm{C}$. Next, $200 \mu \mathrm{L}$ of $20 \%$ sodium dodecyl sulfate were added and incubated for $20 \mathrm{~min}$ at $65^{\circ} \mathrm{C}$, followed by the addition of $30 \mu \mathrm{L}$ of proteinase $\mathrm{K}(10 \mathrm{mg} / \mathrm{mL})$ and incubation overnight at $65^{\circ} \mathrm{C}$. A total of $1.15 \mathrm{~mL}$ of $5 \mathrm{M}$ $\mathrm{NaCl}$ was then added, gently mixed in ice for $15 \mathrm{~min}$, and centrifuged at $3900 \mathrm{x} g$ for $20 \mathrm{~min}$ at $4^{\circ} \mathrm{C}$. The supernatant was mixed with an equal volume of isopropanol and centrifuged at $17000 \mathrm{x} \mathrm{g}$ for $20 \mathrm{~min}$ at $4^{\circ} \mathrm{C}$. The pellet was washed with $70 \%$ ethanol, air dried, and dissolved in $100 \mu \mathrm{L}$ TE buffer. DNA was 
quantified by spectrophotometry (NanoDrop, Wilmington, USA) and samples were stored at $-20^{\circ} \mathrm{C}$ until further use.

\section{Eric-PCR}

amplification

and

electrophoretic analyses: ERIC primers were used as follows: ERIC 1R (5'ATGTAAGCTCCTGGGGATTCAC-3') and ERIC

(5'-AAGTAAGTGACTGGGGTGAGCG-3') (Versalovic et al., 1991). PCR assays were performed in a $20 \mu \mathrm{l}$ reaction mixture containing $30 \mathrm{ng}$ of template DNA, $50 \mathrm{mM}$ $\mathrm{KCl}, 20 \mathrm{mM}$ Tris- $\mathrm{HCl}(\mathrm{pH}$ 8.4), $0.5 \mu \mathrm{M}$ of each primer, $2.5 \mathrm{mM} \mathrm{MgCl}_{2}, 150 \mu \mathrm{M}$ deoxynucleoside triphosphate mixture and $1 \mathrm{U}$ of Taq DNA polymerase (Invitrogen). PCR amplifications were performed under the following conditions: $1 \mathrm{~min}$ at $94^{\circ} \mathrm{C}, 1 \mathrm{~min}$ at $50^{\circ} \mathrm{C}$, and 2 min at $72^{\circ} \mathrm{C}, 41$ cycles with a final temperature of $20^{\circ} \mathrm{C}$. Eric-PCR patterns were visualized by agarose gel electrophoresis. Amplification products were loaded onto 1.2\% agarose gel and run in TAE buffer $1 \mathrm{X}$ at 50 $\mathrm{V}$ during $1 \mathrm{~h}$. Gel was stained with $1 \mu \mathrm{g}$ of ethidium bromide/mL and documented with a Gel Logic 200 (Kodak, Rochester, USA).

Plasmid DNA Extraction: $B$. thuringiensis strains 344 and 1644 were cultivated in 200 $\mathrm{mL}$ of Luria-Bertani (LB) medium, at 200 rpm and $28^{\circ} \mathrm{C}$ until O.D. ${ }_{600 \mathrm{~nm}}$ was between 1.5 and 2.0. The culture cells were centrifuged at $8000 \mathrm{x} \mathrm{g}$ for 10 minutes at $4^{\circ} \mathrm{C}$ and the pellet resuspended in $10 \mathrm{~mL}$ of solution $\mathrm{A}(20 \mathrm{mM}$
Tris- $\mathrm{HCl} \mathrm{pH}$ 8.0; 5 mM EDTA pH 8.0; 20\% sucrose), containing $15 \mathrm{mg} / \mathrm{mL}$ of lysozyme. Samples were incubated at $37^{\circ} \mathrm{C}$ for 90 minutes and $20 \mathrm{~mL}$ of solution $\mathrm{B}$ were added $(0.2 \mathrm{M}$ $\mathrm{NaOH}$ e $0.1 \%$ SDS). Suspensions were mixed up and maintained at room temperature for 5 minutes. Ten $\mathrm{mL}$ of solution $\mathrm{C}$ (3 M potassium acetate $\mathrm{pH} 5.5$ ) were added to the samples and homogenized, maintained in ice for 15 minutes and centrifuged at $8000 \times \mathrm{g}$ for 10 minutes at $4^{\circ} \mathrm{C}$. Supernatant was removed, filtered through two layers of sterile gaze and $25 \mathrm{~mL}$ of isopropanol added to the supernatant. This solution was incubated at $-20^{\circ} \mathrm{C}$ for one hour. Samples were centrifuged again at $8000 \mathrm{x}$ g for 20 minutes and the supernatant discarded. Pellet was dried at room temperature and resuspended in $10 \mathrm{~mL}$ of TE (10 mM Tris; 1 mM EDTA; $\mathrm{pH}$ 8.0).

Plasmid DNA Purification with cesium chloride ultracentrifugation: During plasmid DNA purification, $11 \mathrm{~g}$ of cesium chloride were added in each sample, which was homogenized until complete dissolution. Then, $800 \mu \mathrm{L}$ of ethidium bromide $(10 \mathrm{mg} /$ $\mathrm{mL})$ were added and the samples transferred to new tubes and centrifuged at $150000 \mathrm{x}$ g for 24 hours at $20^{\circ} \mathrm{C}$. Under a UV light, the band containing the plasmid DNA was removed and transferred to a $1.5 \mathrm{~mL}$ microtube. Ethidium bromide removal was done by adding one volume of 1-butanol saturated with water. Samples were agitated for 5 minutes and centrifuged at $10000 \mathrm{x} \mathrm{g}$ for 3 minutes at room 
temperature. The organic phase was discarded and to the inferior phase an equal volume of 1-butanol saturated with water was added. This procedure was repeated four times until the organic phase was completely clear. This phase was transferred to a new microtube and three volumes of water were added. Plasmids were precipitated with two volumes of absolute ethanol and incubated during 30 minutes at $4^{\circ} \mathrm{C}$. After centrifugation at $16000 \mathrm{x} \mathrm{g}$ for 20 minutes, the supernatant was discarded and the pellet washed with $200 \mu \mathrm{L}$ of ethanol $70 \%$. The samples were centrifuged at $16000 \mathrm{x}$ g for 10 minutes and the supernatant discarded. Pellet was dried at room temperature, resuspended in $50 \mu \mathrm{L}$ of TE $(10 \mathrm{mM}$ Tris; $1 \mathrm{mM}$ EDTA; $\mathrm{pH}$ 8.0) and quantified in spectrophotometer (NanoDrop, Wilmington, USA).

\section{DNA electrophoretic analysis: Plasmid DNA} samples were analyzed in $0.5 \%$ agarose gel with TAE buffer $1 \mathrm{X}$, and $1.5 \mu \mathrm{g}$ of plasmid DNA was used to load a gel that ran at $10 \mathrm{~V}$ for 16 hours. The agarose gel was dyed for one hour with ethidium bromide at $1 \mu \mathrm{g} / \mathrm{mL}$ and the excess washed with deionized water for one hour. Plasmid DNA was observed under the UV light and registered in the Gel Logic 200 (Kodak, Rochester, USA).

Protein electrophoresis: Protein analysis were performed by using sodium dodecyl sulfatepolyacrylamide gel electrophoresis (10\% SDSPAGE). Bacterial strains 344 and 1644 were cultivated in $50 \mathrm{~mL}$ of Luria-Bertani (LB) for four days at $30^{\circ} \mathrm{C}$ under continuous shaking. The culture cells were centrifuged at $16000 \mathrm{x}$ $\mathrm{g}$ for 10 minutes and the pellet resuspended in $10 \mathrm{~mL}$ of $0.01 \%$ triton. This procedure was repeated three times. In the last wash, $5 \mathrm{~mL}$ of $0.01 \%$ triton was added with $50 \mathrm{mM}$ Tris$\mathrm{HCl} \mathrm{pH} 8.0$ and $10 \mathrm{mM} \mathrm{NaCl}$. The mixture was centrifuged at $16000 \mathrm{x} \mathrm{g}$ for 5 minutes and pellet was resuspended in $5.0 \mathrm{~mL}$ of 50 $\mathrm{mM}$ buffer bicarbonate $\mathrm{pH} 10.5$ with $10 \mathrm{mM}$ $\beta$-mercaptoetanol and incubated for 3 hours at $37^{\circ} \mathrm{C}$ under constant shaking. Samples were centrifuged at $16000 \mathrm{x}$ g for 10 minutes. The supernatant was incubated with trypsin (200 $\mu \mathrm{g} / \mathrm{mL}$ ) at $37^{\circ} \mathrm{C}$ for two hours. Reaction was inactivated with $1 \mathrm{mM}$ PMSF. Polyacrylamide gel was run at $10 \mathrm{~mA}$ for one hour.

\section{Results and Discussion}

\section{B. thuringiensis strains and subspecies} identification: $B$. thuringiensis strain 344 was identified as Bacillus thruringiensis sv tolworthi serovar $\mathrm{H} 9$ by Institute Pasteur, IEBC number T09 046. Strain 1644 was identified only as Bacillus thuringiensis. Strain 344 has bipyramydal crystals and the strain 1644 cuboid crystal, both confirmed using Scanning Electron Microscope analysis (Figure 1) (Valicente \& Souza 2004).

Bioassay with $B$. thuringiensis and $\mathrm{LC}_{50}$ : Lethal concentration 50 was determined using doses ranging from $10^{3}$ to $10^{9}$ spores $/ \mathrm{mL}$ against two-day-old healthy fall armyworm 
A)

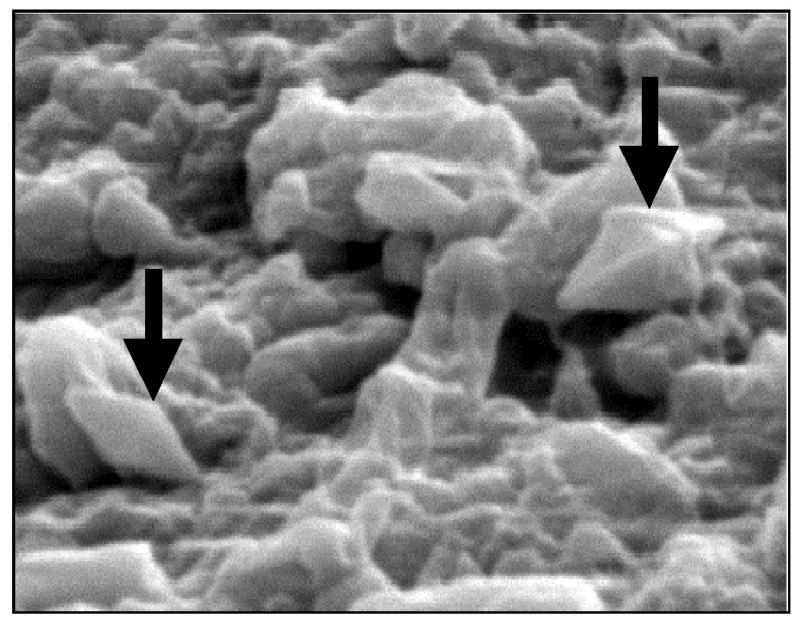

B)

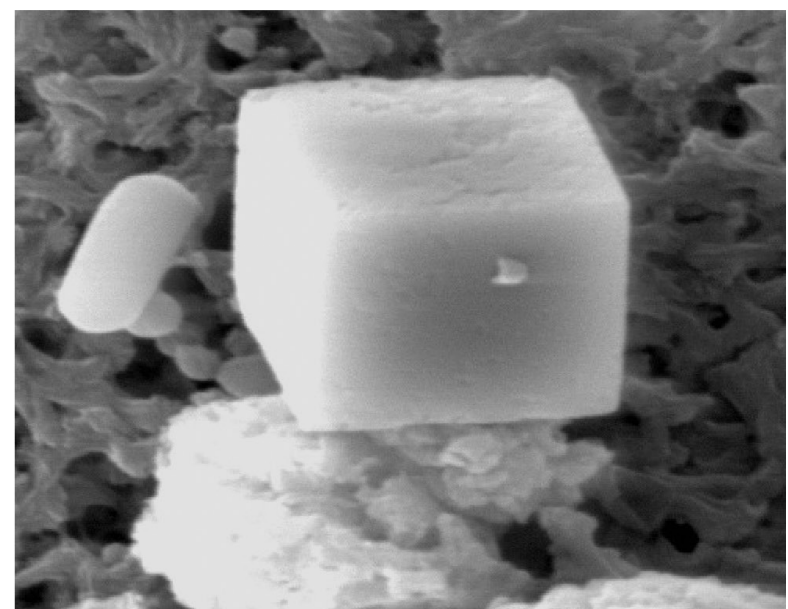

FIGURE 1. Crystal protein of Bacillus thuringiensis. A) Strain 344 with a bipyramidal shape - Scanning Electron Microscope analysis with magnification of 20,000X. B) Strain 1644 with a cuboid shape - Magnification of 10,000X (Valicente \& Souza, 2004).

larvae. $\mathrm{LC}_{50}$ was $8.21 \times 10^{6}$ spores $/ \mathrm{mL}$ for strain 344 while strain 1644 showed $\mathrm{LC}_{50}$ equal $2.07 \times 10^{6} \mathrm{spores} / \mathrm{mL}$.

Identification of cryl genes: PCR was used to detect cryl genes from strains 344 and 1644 that showed to be efficient in controlling fall armyworm. The expected sizes of the PCR products of the cryl genes ranged from $130 \mathrm{bp}$ to $418 \mathrm{bp}$. Strain 344 harbors genes cryl $A b$, cry $l B$, cry $l E$ and $c r y l F b$. A product size for crylB was $367 \mathrm{bp}$, crylE $147 \mathrm{bp}$ and crylFb was 177 bp (Céron et al., 1994; Céron et al., 1995). Another set of primers was used, cry $1 \mathrm{Ab} 51320 \mathrm{~F}$ and cry $1 \mathrm{Ab} 51740 \mathrm{R}$, to verify cry $1 A b$ gene that generated a PCR product of $418 \mathrm{bp}$ (Valicente, data not published). Strain 1644 harbors $c r y 1 B$, crylC, with $130 \mathrm{bp}$ fragment, crylD (290 bp) and crylFb genes. Some of these results are shown on Figure 2.
The strain 344, although also very efficient in killing fall armyworm, does not harbor cry $1 C$ gene. Our data are in agreement with those reported by Loguercio et al. (2001) who showed that the presence of the crylC genes does not necessarily correlate with high toxicity to $S$. frugiperda larvae and suggest that other proteins present in the $B t$ strains analyzed might be more important for toxicity. These findings are corroborated by Valicente $\&$ Fonseca (2004). Additionally, other factors, such as differences in toxin expression or synergistic effects between some cry toxins, could account in toxicity of $B t$ strains (Monnerat et al., 2006).

ERIC-PCR: The amplification with ERIC primers of 344 and $1644 B t$ strains revealed multiple bands, ranging between 200 and 3000 bp (Figure 3). The 344 strain presented a 

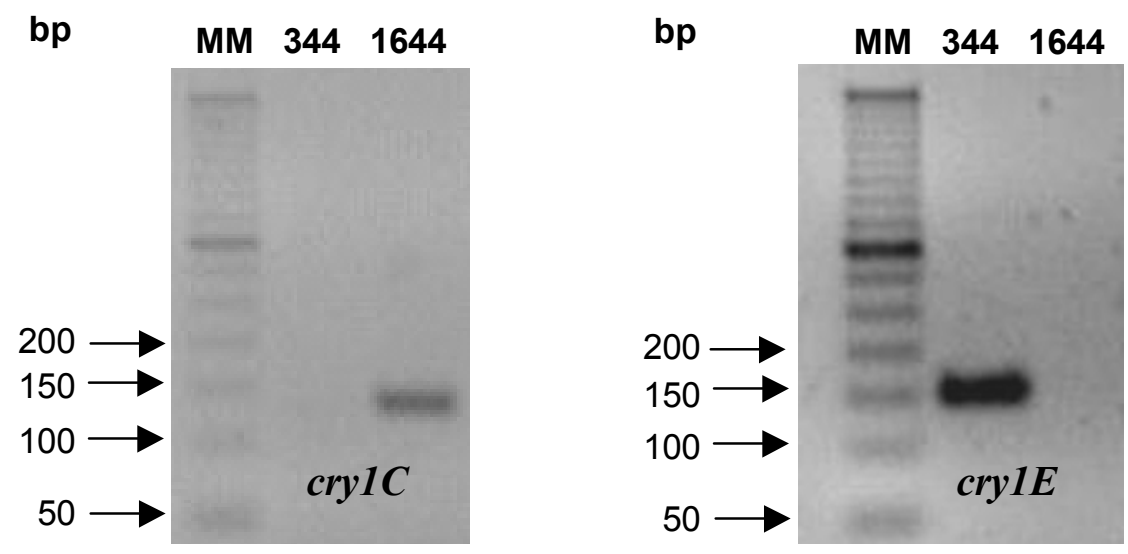

FIGURE 2. PCR analysis of the cryIC and cryIE genes of the strains 344 and 1644. MM Molecular weight 50 pb Ladder (Invitrogen).

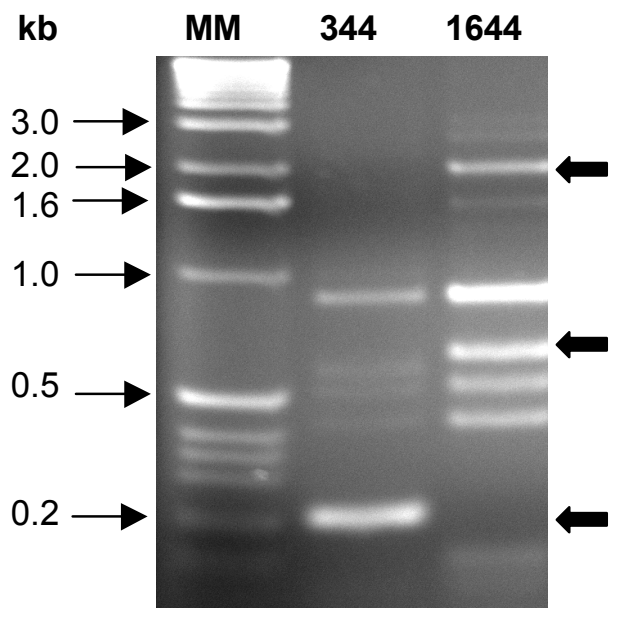

FIGURE 3. Comparative analysis of the strains 344 and 1644 based on PCR-amplified fragment bands using ERIC1-R and ERIC2 primers. MM - Molecular weight $1 \mathrm{~Kb}$ Ladder (Invitrogen). 
fragment of approximately $200 \mathrm{bp}$ allowing its differentiation from the 1644 strain. Diversely from 344 strain, 1644 strain showed at least two unique bands with sizes around 750 and 2000 bp. With ERIC-PCR, strain 344 was discriminated from the 1644, indicating that these strains are genetically different. This technique has been used for strain identification and for target prevision, without the need to carry out all the tedious and timeconsuming bioassays (Carozzi et al., 1991). The use of repetitive DNA sequences such as ERIC for bacterial classification is becoming frequent, and has allowed comparisons of possible genetic similarities among different bacterial genomes (Versalovic et al., 1991; Louws et al., 1994; Selenska-Pobell et al., 1995). Our study supports the data presented by Shangkuan et al. (2001) and Lima et al. (2002) that revealed that ERIC elements are present in the genomes of Bt. Our results also support the conclusion of De Bruijn (1992) that the ERIC PCR could become a powerful tool to differentiate strains of microorganisms. ERIC-PCR fingerprint analyses of $B t$ strains showed to be simple, fast, and reproducible, it may become a standardized characterization procedure.

\section{Plasmid pattern of $\boldsymbol{B}$. thuringiensis strains:}

In this work we compared the plasmid patterns of two $B t$ strains. While strain 344 presented about 11 plasmids, strain 1664 showed at least eight. The relevance of plasmids in $B t$ strains is assumed by the regular presence of a set of plasmids, which can vary in number from 1 to 17 (Aptosoglou et al., 1997; Gonzáles \& Carlton, 1980). The profile of strains indicated plasmids of different sizes, ranging from $3 \mathrm{~kb}$ to higher values than $12 \mathrm{~kb}$ (Figure 4). These variations in the number and molecular weight of the DNA plasmid represent the

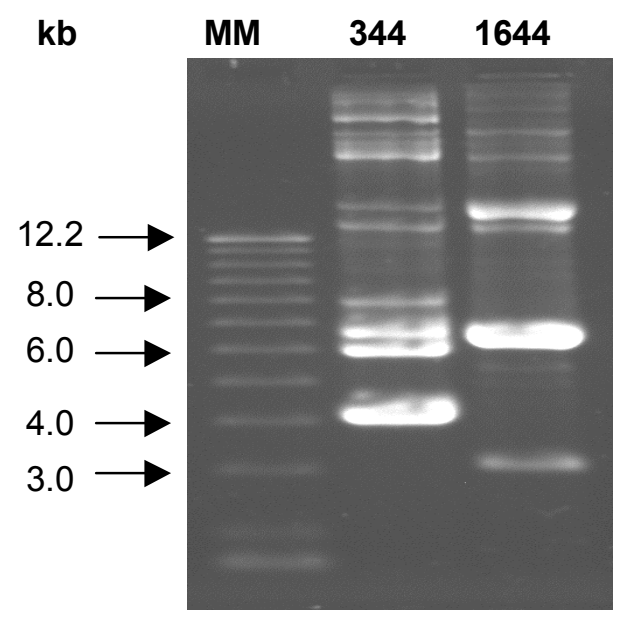

FIGURE 4. Plasmid pattern of Bacillus thuringiensis strains 344 and 1644. MM - Molecular weight $1 \mathrm{~Kb}$ Ladder (Invitrogen). 
genetic divergence between the strains of that species. Although Bt plasmids have been studied either to locate cry genes or to transfer them to different strains and species, plasmid patterns have frequently been used to characterize strains (Ibarra \& Federici, 1987; Ibarra et al., 2003). Reyes-Ramírez \& Ibarra (2008) evaluated the plasmid patterns of several strains of $\mathrm{Bt}$ and observed that, with one exception, all strains showed a unique plasmid pattern. In this report, we were able to compare the plasmid patterns of the strains 344 and 1644 of Bt. These strains also showed a unique plasmid pattern and the results obtained are supported by Reyes-Ramírez \& Ibarra (2008). The information obtained from this comparison showed the importance of this tool as a strain characterization procedure and indicates the complexity and uniqueness of this feature.

Protein electrophoresis: SDS-PAGE profile shows that the strains 344 and 1644 harbour multiple and different protein profiles, with molecular masses ranging from 30 to $205 \mathrm{kDa}$. Strain 344 showed an active toxin fragment of $60 \mathrm{kDa}$ after trypsin digestion, while strain 1644 showed a toxic fragment of $55 \mathrm{KDa}$ (Figure 5).

Morphological characterization of crystal inclusions of the selected $B t$ strains showed typical bipyramidal and cuboidal crystals, common to most lepidopteran-active strains. These data are in agreement with the

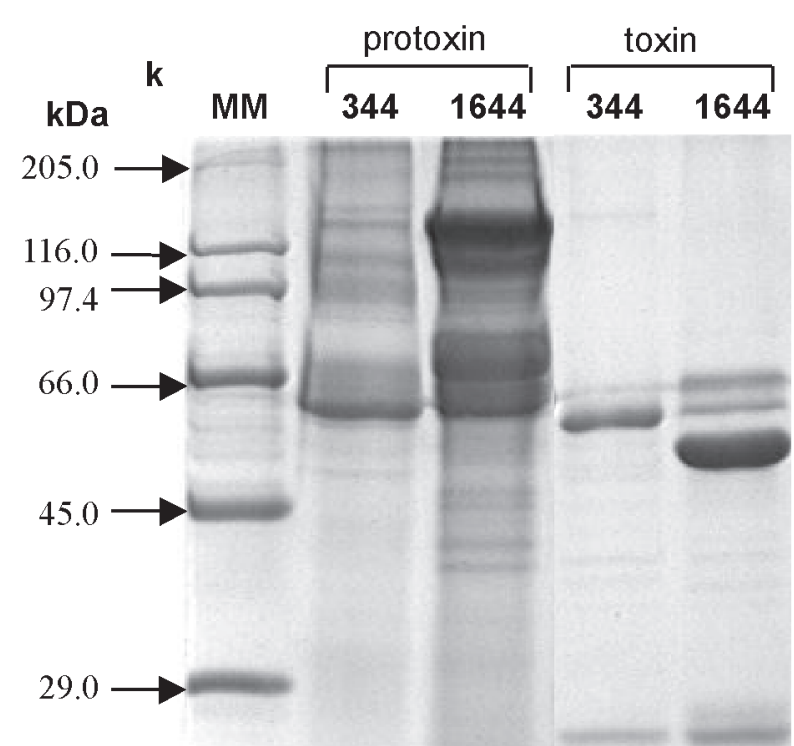

FIGURE 5. Protein analysis of strains 344 and 1644. MM - Molecular Marker SDS 6H (Sigma). 
protein composition observed in the SDSPAGE analysis. However, a high diversity of plasmid profiles was observed, suggesting important variability among these $B t$ strains, which agrees with the different cry gene contents found in these strains.

\section{Conclusions}

Comparative analyses of cry genes, amplification with ERIC primers, plasmid pattern and protein profile allowed the clear differentiation of the evaluated strains. It may also help in the establishment of a new subspecies-level classification of Bt. Due to this discrimination, these analysis can be an useful tool in the characterization of $B t$ strains, something highly valuable in intellectual property claims.

\section{Literature Cited}

APTOSOGLOU, S. G.; SIVROPOULOU, A.; KOLIAIS, S. I. Plasmid patterns of Bacillus thuringiensis strains and isolates. Microbios, Cambridge, v. 91, p. 203-214, 1997.

ARONSON,A.E.;HAN,E.S.; MCGAUGHEY, W.; JOHNSON, D. The solubility of inclusion proteins form Bacillus thuringiensis is dependent upon protein composition and is a factor in toxicity to insects. Applied and Environmental Microbiology, Washington, v. 57, p. 981-986, 1991.
BAUM, J. A.; JOHNSON, T. B.; CARLTON, B. C. Bacillus thuringiensis: natural and recombinant bioinsecticide products. In: HALL, F. R.; MENN, J. J. (Ed.). Biopesticides: use and delivery. Totowa: Humana Press, 1999. p. 189-209.

BEEGLE, C. C.; YAMAMOTO, T. Invitation paper (C.P. Alexander Fund): History of Bacillus thuringiensis Berliner Research and Development. Canadian Entomologist, Ottawa, v. 124, p. 587-616, 1992.

BERHNARD, K.; JARRET, P.; MEADOWS, M.; ELLIS, D. J.; ROBERTS, G. M.; PAULI, S.; RODGERS, P.; BURGES, H. D. Natural isolates of Bacillus thuringiensis: wordwine distribution, characterization, and activity against insects pests. Journal of Invertebrate Pathology, New York,v. 70, p. 59-68, 1997.

BOUCIAS, D. G.; PEDLAND, J. C. Principles of insect pathology. Boston: Kluwer Academic Publishers, 1998. 537 p.

CAROZZI, N. B.; KRAMER, V. C.; WARREN, G. W.; EVOLA, S.; KOZIEL, M. G. Prediction of insecticidal of Bacillus thuringiensis strains by polymerase chain reaction product profiles. Applied and Environmental Microbiology, Washington, v. 57, p. 3057-3061, 1991.

CARVALHO, R. P. L. Danos, flutuação da população, controle e comportamento de Spodoptera frugiperda (J.E. Smith) e susceptibilidade de diferentes genotipos de milho em condições de campo. 
Piracicaba.1970. 170 f. Tese (Doutorado em Entomologia) - Escola Superior de Agricultura "Luiz de Queiroz", Universidade de São Paulo, Piracicaba.

CÉRON, J.; COVARRUBIAS, L.; QUINTERO, R.; ORTIZ, A.; ORTIZ, M.; ARANDA, E.; LINA, L.; BRAVO, A. PCR analysis of the cryI insectidal crystal family genes from Bacillus thuringiensis. Applied and Environmental Microbiology, Washington, v. 60, p.353-356, 1994.

CÉRON, J.; ORTIZ, A.; QUINTERO, R.; GUERECA, L.; BRAVO, A. Specific PCR primers directed to identify cryI and cryIII genes within a Bacillus thuringiensis strain collection. Applied and Environmental Microbiology, Washington, v. 61, p. 38263831, 1995.

DE BRUIJN F. J. Use of repetitive (repetitive extragenic palindromic and enterobacterial repetitive intergeneric consensus) sequences and the polymerase chain reaction to fingerprint the genomes of Rhizobium meliloti isolates and other soil bacteria. Applied and Environmental Microbiology, Washington, v. 58, p. 2180-2187, 1992.

GLARE, T. R.; O'CALLAGHAN, M. Bacillus thuringiensis: biology, ecology and safety. Chichester: J. Wiley, 2000. 350 p.

GONZÁlez, J. M.; CARLTON, B. C. Patterns of plasmid DNA in crystalliferous and acrystalliferous strains of Bacillus thuringiensis. Plasmid, New York, v. 3, p. 9298, 1980.

GONZÁLEZ JUNIOR, J. M.; BROWN, B. J.; CARLTON, B. C. Transfer of Bacillus thuringiensis plasmids coding for d-endotoxin among strains of Bacillus thuringiensis and Bacillus cereus. Proceedings of the National Academy of Sciences, Washington, v. 79, p. 6951-6955, 1982.

HULTON, C. S.; HIGGINS, C. F.; SHARP, P. M. ERIC sequences: a novel family of repetitive elements in the genomes of Escherichia coli, Salmonela typhimurium and other enterobacteria. Molecular Microbiology, Oxford,v. 5, p. 825-834, 1991.

IBARRA, J. E.; FEDERICI, B. A. Comparison of the toxicity parasporal body protein composition, and plasmid complements of nine isolates of Bacillus thuringiensis subsp. israelensis. Journal of Economic Entomology, College Park, v. 80, p. 11321136, 1987.

IBARRA, J. E.; RINCÓN, M. C. del; ORDÚZ, S.; NORIEGA, D.; BENINTENDE, G.; MONNERAT, R.; REGIS, L.; OLIVEIRA, C. M. F.; LANZ, H.; RODRIGUEZ, H.; SÁNCHEZ, J.; PENA, G.; BRAVO, A. Diversity of Bacillus thuringiensis strains from Latin America with insecticidal activity against different mosquito species. Applied and Environmental Microbiology, Washington, v. 69, p. 5269-5274, 2003. 
KRONSTAD, J. W.; SCHNEPF, H. F.; WHITELEY, H. R. Diversity of locations for Bacillus thuringiensis crystal protein genes. Journal of Bacteriology, Washington, v.154, p. 419-428, 1983.

LAMBERT, B.; PEFEROEN, M. Insecticidal promise of Bacillus thuringiensis. Bioscience, Washington, v. 42, p. 112-122, 1992.

LIMA, A. S. G.; GUIDELLI, A. M.; ABREU, I. L.; LEMOS M. V. F. Identification of new isolates of Bacillus thuringiensis using rep-PCR products and -endotoxin electron microscopy. Genetics and Molecular Biology, Ribeirão Preto, v. 25, p. 225-229, 2002.

LOUWS, F. J.; FULBRIGHT, D. W.; STEPHENS, C. T.; de BRUIJN, F. J. Specific genomic fingerprint of phytopathogenic Xanthomonas and Pseudomonas pathovars and strains generated with repetitive sequence and PCR. Applied and Environmental Microbiology, Washington, v. 60, p. 22862295, 1994.

LOGUERCIO, L. L.; SANTOS, C. G.; BARRETO, M. R.GUIMARAES, C. T.; PAIVA, E. Association of PCR and feeding bioassays as a large-scale method to screen tropical Bacillus thuringiensis isolates for a cry constitution with higher insecticidal effect against Spodoptera frugiperda (Lepidoptera: Noctuidae) larvae. Letters in Applied Microbiology, Oxford, v. 32, p. 362-367, 2001.
MONNERAT, R.; MARTINS, E.; QUEIROZ, P.; ORDÚZ, S.; JARAMILLO, G.; BENINTENDE, G.; COZZI, J.; REAL, M. D.; MARTINEZ-RAMIREZ, A.; RAUSELL, C.; CERÓN, J.; IBARRA, J. E.; RINCON-CASTRO, M. C. del; ESPINOZA, A. M.; MEZA-BASSO, L.; CABRERA, L., SÁNCHEZ, J.; SOBERON, M.; BRAVO, A. Genetic variability of Spodoptera frugiperda Smith (Lepidoptera: Noctuidae) populations from Latin America is associated with variations in susceptibility to Bacillus thuringiensis Cry toxins. Applied and Environmental Microbiology, Washington, v. 72, p. 7029-7035, 2006.

NAKAMURA, L. K.; DULMAGE, H. T. Bacillus thuringiensis cultures available from the U. S. Department of Agriculture. [S.1.]: USA-ARS, 1988. 38 p. (USA-ARS. Technical Bulletin, 1738).

PHUCHAROEN, K.; CHUGJATUPORNCHAI, W.; PANYIM, S. Differentiation of Bacillus thuringiensis subspecies using repetitive extragenic palindromic PCR (REP-PCR) genomic fingerprinting. Asia Pacific Journal of Molecular Biology and Biotechnology, Kuala Lumpur, v. 7, p. 79-83, 1999.

REYES-RAMÍREZ, A.; IBARRA, J. E. Plasmid Patterns of Bacillus thuringiensis Type Strains. Applied and Environmental Microbiology, Washington, v. 74, p. 125-129, 2008. 
SELENSKA-POBELL， S.; GIGOVA， L.; PETROVA, N. Strain-specific fingerprints of Rhizobium galegae generated by PCR with arbitrary and repetitive primers. Journal of Applied Bacteriology, London, v. 79, p. 425431, 1995.

SHANGKUAN, Y. H.; CHANG, Y. H.; YANG, J. F.; LIN, H. C.; SHAIO, M. F. Molecular characterization of Bacillus anthracis using multiplex PCR, ERIC-PCR and RAPD. Letters and Applied Microbiology, Oxford, v. 23, p. 139-145, 2001.

VALICENTE, F. H.; BARRETO, M. R. Bacillus thuringiensis Survey in Brazil: Geographical distribution and insecticidal activity against Spodoptera frugiperda (J.E.Smith) (Lepidoptera: Noctuidae). Neotropical Entomology, Londrina, v. 32, p. 639-644, 2003.
VALICENTE, F. H.; FONSECA, M. M. Susceptibilidade da lagarta do cartucho do milho, Spodoptera frugiperda a diferentes isolados de Bacillus thuringiensis. Revista Brasileira de Milho e Sorgo, Sete Lagoas, v. 3, p. 21-29, 2004.

VALICENTE, F. H.; SOUZA, I. R. P. Cultivo e preparo de Bacillus thuringiensis para Microscopia eletronica de varredura. In: CONGRESSO NACIONAL DE MILHO E SORGO, 25.; SIMPÓSIO BRASILEIRO SOBRE A LAGARTA-DO-CARTUCHO, SPODOPTERA FRUGIPERDA, 1., 2004, Cuiabá. Resumos... Sete Lagoas: ABMS/ Embrapa Milho e Sorgo/Empaer, 2004. p.146.

VERSALOVIC, J.; KOEUTH, T.; LUPSKI, J. R. Distribution of repetitive DNA sequences in eubacteria and application to fingerprinting of bacterial genomes. Nucleic Acids Research, London, v. 19, p. 6823-6831, 1991. 
